\title{
Knowledge Level of Cervical Cancer Among Women in Cameroon
}

\author{
Ngwayu Claude Nkfusai ${ }^{1}$ and Samuel Nambile Cumber ${ }^{2 *}$ \\ ${ }^{1}$ Department of Microbiology and Parasitology, University of Buea, Cameroon \\ ${ }^{2}$ Department of Public Health and Community Medicine (EPSO), University of Gothenburg, Sweden
}

Submission: September 14, 2018 ; Published: September 26, 2018

*Corresponding author: Samuel Nambile Cumber, Department of Public Health and Community Medicine (EPSO), University of Gothenburg, Sweden, Tel: +46722614019; Email: samuel.cumber@gu.se

\section{Abstract}

Cervical cancer is a leading cause of dead among women in Africa and Cameroon in particular. It is cancer of the lower portion of the uterus, just above the vagina. Cervical cancer is caused by the Human Papilloma Virus which is transmitted mostly through sexual intercourse. We aimed at finding the reasons why this cancer very common among women in Africa and Cameroon in particular and also to find out if Cameroonian women are aware of the disease using a cross sectional designed study. We found out that more than $50 \%$ of the women never knew or have never heard nor screened for cervical cancer.

\section{Introduction}

Cervical cancer is the second most commonly diagnosed cancer after breast cancer and the third leading cause of cancer death among females in under developed countries. Incidence rates are the highest in countries with low income. Nearly $90 \%$ of cervical cancer deaths occurred in developing parts of the world [1]. Cervical cancer has emerged to become a major public health concern in the $21^{\text {st }}$ century, alongside HIV/AIDS [2]. A crosssectional study was conducted in 6 regions in Cameroon found a national prevalence is $3.9 \%$ and also found a low awareness level of the disease [3]. A study carried out in schools and clinics in the North West Region of Cameroon revealed an awareness of cervical cancer, preventive measures, screening method and HPV vaccination of above $70 \%$ [4].

Table 1:Socio-demographic characteristics of the participants, $\mathrm{N}=433$.

\section{Study Designed}

A cross sectional study among 433 women in the Buea Health District, Fako Division in the South West Region. Questionnaires were given and analyzed almost immediately and the results presented in frequency distribution tables.

\section{Result}

\section{Demographic characteristics}

Over 500 women in Buea Health District were approached. A total of 433 participants were recruited. The average age of the participants was 30.5 years. Most of the participants were married (60.7\%), Farmers (46.7\%) and Christians (98.8\%) (Table 1).

\begin{tabular}{|c|c|c|}
\hline \multicolumn{2}{|c|}{ Frequency (F) } & Percentage (\%) \\
\hline \multicolumn{2}{|c|}{ Age Category } & 32.6 \\
\hline $18-34$ & 141 & 50.8 \\
\hline $35-51$ & 220 & 16.6 \\
\hline $52-68$ & 72 & 1.4 \\
\hline & Level of Education & 40.2 \\
\hline No formal & 6 & 34.4 \\
\hline Primary & 174 & 24 \\
\hline Secondary & 149 & \\
\hline Tertiary & 104 & \\
\hline
\end{tabular}


Journal of Gynecology and Women's Health

\begin{tabular}{|c|c|cc|}
\hline Single & 263 & 60.7 \\
\hline \multicolumn{2}{|c|}{ Religion } & \\
\hline Christian & 428 & \\
\hline Muslim & 5 & 1.2 \\
\hline \\
\hline Business & Occupation & 29.8 \\
\hline Farmers & 129 & 46.7 \\
\hline Others & 202 & 23.5 \\
\hline
\end{tabular}

$\mathrm{N}=$ Sample size .

\section{To determine the knowledge of the participants on cervical cancer}

Table 2: Knowledge of the participants on cervical cancer.

\begin{tabular}{|c|c|c|c|}
\hline & Yes $F(\%)$ & No $F(\%)$ & Don't know F(\%) \\
\hline \multicolumn{4}{|c|}{ Knowledge on Cervical Cancer } \\
\hline Have you heard of cervical cancer & $251(57.8)$ & $183(42.2)$ & \\
\hline Is cervical cancer the 1 st cause of death in women in Cameroon & $183(42.2)$ & $41(9.4)$ & $210(48.4)$ \\
\hline Is cervical cancer caused by a virus & $131(30.2)$ & $28(6.5)$ & $275(63.4)$ \\
\hline Have you heard about HPV & $100(23.0)$ & $334(76.9)$ & \\
\hline Do patients always show symptoms & $50(11.5)$ & $76(17.5)$ & $308(71.0)$ \\
\hline Can cervical cancer be prevented via vaccination & $234(53.9)$ & $22(5.1)$ & $178(41.0)$ \\
\hline Is cervical cancer curable & $192(44.2)$ & $46(10.6)$ & $196(45.2)$ \\
\hline
\end{tabular}

$\mathrm{F}=$ Frequency $\%=$ Percentage

The various frequencies beside each option refer to the number of participants who responded to the question. Using descriptive statistics, about $57.8 \%(95 \% \mathrm{CI}=46 \%-55.37)$ of the study population had heard of cervical cancer (Table 2).

\section{Discussion}

In our study, we recruited 433 participants. Our age range was 18 to 68 years, which was similar to [5] in Nigeria, with an age range of 16 to 65 years. The mean age of the study population was 30.5 years, with a modal age of 21years. However, this was higher than the mean age of 21.5 years obtained by Hoque E [6] in South Africa. Majority of our participants (98.8\%) were Christians and single; this was similar to other studies carried out in other parts of Africa.

$57.8 \%$ of the participants had heard of cervical cancer in the past. This is slightly lower than that carried out by Wamai RG, et al. [4], revealed an awareness of cervical cancer, of above 70\%. The high awareness of cervical cancer among these women could be due to the fact that they are within an Urban area, and thus can easily access information from the internet, mass media, and press prints. Our findings were however higher than the 33\% obtained by Hoque E [6] among female undergraduate students in South Africa. Most of our participants (68\%) had heard about cervical cancer from mass media. This was similar to results obtained by Wright KO [7] in Lagos Nigeria, and by Abotchie PN [8] in Ghana.

\section{Conclusion}

We can conclude therefore that most women in the Buea Health District had good knowledge (57.8\%) and a high level of awareness of cervical cancer.

\section{Authors' contribution}

NCN and SNC conceived and designed the study. NCN implemented the study. NCN conducted data analysis. NCN and SNC interpreted study results: NCN wrote the first draft of the manuscript. SNC reviewed and corrected the draft manuscript. All authors read and approved the final manuscript.

\section{Acknowledgement}

We are grateful to all the women who took part in this study.

\section{References}

1. Torre LA, Bray F, Siegel RL, Ferlay J, Lortet-Tieulent J, et al. (2015) A Global cancer statistic, 2012. CA Cancer J Clin 65(2): 87-108.

2. Morens DM, Folkers GK, Fauci AS (2004) The challenge of emerging and re-emerging infectious diseases. Nature 430(6996): 242-249.

3. Tebeu PM, Major AL, Rapiti E, Petignat P, Bouchardy C, et al. (2008) The attitude and knowledge of cervical cancer by Cameroonian women; a clinical survey conducted in Maroua, the capital of Far North Province of Cameroon. Int J Gynecol Cancer 18(4): 761-765.

4. Wamai RG, Ayissi CA, Oduwo GO, Perlman S, Welty E, et al. (2013) Awareness, knowledge and beliefs about HPV, cervical cancer and HPV vaccines among nurses in Cameroon: An exploratory study. Int J Nurs Stud 50(10): 1399-1406. 
5. Owoeye IO, Ibrahim IA (2013) Knowledge and attitude towards cervical cancer screening among female students and staff in a tertiary institution in the Niger Delta. International Journal of Medicine and Biomedical Research 2(1): 48-56.

6. Hoque E, Hoque M (2009) Knowledge of and attitude towards cervical cancer among female university students in South Africa. Southern African Journal of Epidemiology and Infection 24(1): 21-24.
7. Wright KO, Aiyedehin O, Akinyinka MR, Ilozumba O (2014) Cervical cancer: community perception and preventive practices in an urban neighborhood of Lagos (Nigeria). ISRN preventive medicine, p. 9.

8. Abotchie PN, Shokar NK (2009) Cervical cancer screening among college students in Ghana: knowledge and health beliefs. Int J Gynecol Cancer 19(3): 412-416.

\section{Your next submission with Juniper Publishers will reach you the below assets}

- Quality Editorial service

- Swift Peer Review

- Reprints availability

- E-prints Service

- Manuscript Podcast for convenient understanding

- Global attainment for your research

- Manuscript accessibility in different formats ( Pdf, E-pub, Full Text, Audio)

- Unceasing customer service

Track the below URL for one-step submission https://juniperpublishers.com/online-submission.php 